\title{
Construir, habitar, pensar ${ }^{1}$
}

Build, dwell, think

Construir, habitar, pensar

Victor Hugo de Oliveira Marques²

${ }^{1}$ O texto traduzido no original é: [Bauen, Wohnen, Denken] (1951) e corresponde a uma conferência pronunciada pelo filósofo Heidegger por ocasião da "Segunda Reunião de Darmastad", publicada em Vortäge und Aufsätze, G. Neske, Pfullingen, 1954. Tradução direta de: HEIDEGGER, M. Bauen Wohnen Denken. In: Gesamtausgabe. I. Abteilung: Veröffentlichte Schriften 1910-1976.

Band 7. Vorträge und Aufsätze. Frankfurt am Main: Vittorio Klostermann, 2000, pp.146-165. Esta tradução, apesar de já existir uma para o português,

faz parte do Projeto de Pesquisa em Estudos sobre o Desenvolvimento do Prof. Dr. Josemar Campos Maciel e parte da minha pesquisa de Doutorado em Desenvolvimento Local pela UCDB. Ela procura valorizar os elementos de uma racionalidade ambiental e dos recentes estudos sobre filosofia ambiental, principalmente à luz a compreensão de Enrique Leff, e tem por objetivo fazer uma compreensão sobre o desenvolvimento.

${ }^{2}$ Docente e Coordenador do Curso de Filosofia da Universidade Católica Dom Bosco (UCDB). Doutorando em Desenvolvimento Local pela UCDB.

E-mail:vicgo@bol.com.br 
Na sequência, tentaremos pensar sobre habitar ${ }^{1}$ e construir. Esse pensar sobre o construir não pretende encontrar teorias sobre construção ou mesmo oferecer regras para construir. Aqui esta experiência do pensar representa o construir em geral, não desde a arquitetura e a técnica, mas sim ela persegue de volta o construir naquele âmbito onde pertence aquele que é.

Perguntamos: 1. O que é o habitar?

2. Até que ponto o construir pertence ao habitar?

\section{I}

Só chegamos a habitar, assim parece, por meio do construir. Este, o construir, tem aquele, o habitar, por objetivo. No entanto nem todas as construções são também habitações. Ponte e hangar, estádio e usina elétrica são construções, mas não habitações; estação ferroviária e autoestrada, barragem e estrutura de um mercado são construções, mas não habitações. Não obstante a essa separação, as construções indicadas estão no âmbito de nosso viver ${ }^{2}$. Vai além dessas construções e, novamente, não se limita ao espaço físico ${ }^{3}$. O caminhoneiro na autopista se sente em casa, mas ele não tem ali seu alojamento; a operária na tecelagem se sente em casa, ainda que não tenha ali sua moradia; o engenheiro sênior na usina elétrica se sente em casa, mas ele não reside ali. As construções indicadas hospedam os homens. Ele as habita e, todavia, não habita nelas, quando habitar apenas quer dizer que nós temos uma residência. Com a atual crise habitacional, mantê-las, sem dúvida, já tranquiliza e agrada; edifícios habitacionais atendem bem como moradia, hoje as habitações podem até ser organizadas, fáceis de administrar, desejavelmente baratas, abertas em direção ao ar, luz e sol, mas: as habitações já põem a salvo a mesma garantia

\footnotetext{
${ }^{1}$ Heidegger quer marcar a diferença entre o habitar fisicamente em algum lugar e o pertencer junto a algum lugar como um modo de ser-vivente. Para marcar esta diferença, traduzimos 'Wohnen' por habitar, ou seja, deter-se fisicamente em um lugar (N. do T.).

${ }^{2}$ O termo 'Wohnens', pelo contexto, parece referir-se não ao habitar físico, mas como modo de viver (N. do T.).

${ }^{3}$ Optamos aqui, pelo contexto, traduzir 'Wohnung' por 'espaço físico' (N. do T.) 
que ocorre em um habitar? Cada uma das construções, no entanto, não são habitações, por seu lado, elas permanecem aqui determinadas pelo habitar, contanto que sirvam de habitar aos homens. É somente, pois, em cada caso, que o habitar poderia ser [147] ${ }^{4}$ fim, fato esse que normalmente determina o construir. Habitar e construir estão um para o outro em uma relação de fim e meio. Desse modo, enquanto cremos nisto, tomamos habitar e construir por duas atividades separadas e apresentamos com isto algo correto. Porém, ao mesmo tempo, alteramos por meio do esquema fim-meio sua referência essencial.

Construir, a saber, não é apenas meio e acesso ao habitar, o construir já é em si mesmo ${ }^{5}$ habitar. Quem nos diz isto? Quem nos dará, de modo geral, a medida pela qual atravessaremos ${ }^{6}$ a essência de habitar e construir? A exigência ${ }^{7}$ pela essência de uma coisa chega até nós pela linguagem, supondo que respeitemos sua própria essência. Entrementes, sem dúvida, correm desenfreados e ao mesmo tempo discursos, cartas e transmissão falada por todo o Globo. O homem se comporta como se ele fosse o formador e mestre da linguagem, enquanto, na verdade, esta permanece senhora dos homens. Talvez seja, antes de qualquer coisa, a inversão praticada pelos homens desta relação de poder que mova sua essência no não familiar. Que nos detenhamos ao cuidado da linguagem, isto é bom, mas não ajuda muito, enquanto, ainda com isto, a linguagem apenas nos servir como um meio de expressão. A todo custo que nós, homens, desde nós mesmos, somos capazes de produzir junto com a linguagem, pois, extremamente e em toda a parte, a linguagem é anterior.

\footnotetext{
${ }^{4}$ Estas numerações marcam o fim da página no texto original em alemão (N. do T).

${ }^{5}$ De acordo com o Dicionário DUDEN, o termo 'selber' é o uso coloquial de 'selbst', que significa 'mesmo' (N. do T.).

6 'Durchmesser' é um termo que pode ser traduzido por 'diâmetro'. O verbo 'durchmessen', portanto, dá a ideia de uma ação que toma alguma coisa "de ponta a ponta", tal como a medida do diâmetro. Nas outras traduções encontramos as seguintes significações: 'tomar a medida' (inglês), medir de um cabo a outro (espanhol), dimensionar (português). Optamos pela tradução do Dicionário BLAB.LA: 'atravessar' (N. do T.)

${ }^{7}$ O termo 'Zuspruch' é de difícil tradução. Segundo o Dicionário DUDEN, ele tem o sentido de consolo, encorajamento e persuasão. Mas pode ser também aprovação, ovação e concessão. As traduções que encontramos deste texto nos fala de 'dizer' (inglês), exortar (espanhol) e acesso no português. Optamos por exigir (N. do T.)
} 
O que quer dizer, então, construir? A palavra construir no antigo alto-alemão ${ }^{8}$ é "buan", e significa habitar ${ }^{9}$. Isto quer dizer: permanecer, morar. O significado original do verbo alemão construir, enquanto habitar, nos é dado como perdido. Uma pista, ainda que oculta, a respeito desse antigo significado tem se conservado na palavra alemã "Nachbar"10. O Nachbar é o "Nachgebur", o "Nachgebauer"11, aquele que mora na proximidade. Os verbos buri, büren, beuren, beuron significam todos morar, o lugar onde alguém vive. Logo, sem dúvida, esta antiga palavra baun, originalmente não nos diz apenas morar, mas sim ela nos dá, ao mesmo tempo, uma indicação de como podemos pensar isso desde aquele indicado habitar. Quando a questão é o habitar, habitualmente pensamos em um comportamento que nada difere de muitas outras formas de comportamento que o homem realiza [148] ${ }^{12}$. Trabalhamos aqui e moramos ali. Nós não só moramos, isto

${ }^{8}$ De acordo com Coutinho (s.d.) citando Bunse (1983), o 'germânico comum', que se fragmentou da língua indo-europeia, era formado por três grupos: o germânico oriental, representado pelo gótico; o germânico setentrional, representado pelo islandês, sueco, norueguês e dinamarquês; e o germânico ocidental, representado pelo neerlandês, frísio, iídiche, baixo-alemão, alto-alemão e inglês. Tanto o alemão quanto o inglês são fruto do grupo lingüístico germânico ocidental. Especificamente, o alemão provém dos dialetos desenvolvidos pelos povos mais ao sul da Alemanha denominada de alto-alemão (Hochdeutsch). Esta língua, por seu turno, foi usualmente utilizada pelos francos, alamânicos e bávaros; e sua evolução se dá em três grandes períodos: o Antigo alto-alemão (VIII a 1070), Médio alto-alemão (1070-1350) e Moderno alto-alemão (1350 a atualidade. Heidegger lança mão do Antigo alto-alemão (Althochdeutsch), que é a fase inicial do alemão moderno. Uma de suas características, como indica Coutinho (s.d.), é a mudança na estrutura da forma: de uma estrutura sintética para uma mais analítica. Pela própria teoria da linguagem que Heidegger assume, a formação e a assunção original de uma língua é também a constituição originária dos mesmos, determinando seus diversos modos de ser e estar dado no mundo (N. do T.) ${ }^{9} \mathrm{O}$ verbo ,bauen', originalmente reduplicado com o som -w- no antigo alto-alemão era buwan, buwen e significava wohnen, bewohnen, Arkebau treiben [cultivar o solo] (séc. VIII). O termo referido por Heidegger parece remeter mais ao saxônico ou a inglês, 'buan'. Cf. DWDS in: http://www.dwds.de/?view=1\&qu=Bauen. (N. do T).

10 Em português, significa "vizinho".

${ }^{11}$ Nachbar, originariamente no antigo alto-alemão era 'nachgibur', nachgiburo (séc. VIII). O que Heidegger quer salientar é o caráter de justaposição entre Nahe (próximo) e Bauer (morar), compondo o sentido de morar nas redondezas, vizinhança. Cf. DWDS in: http:// www.dwds.de/?view=1\&qu=Nachbar .

${ }^{12}$ Construímos essa proposição menos na literalidade do original e mais no sentido que as traduções pelas quais tomamos por base nos ofereceram (N. do T.) 
seria quase inatividade, nós estamos em uma profissão, fazemos negócios, viagens e nos acomodamos pelo caminho, ora aqui, ora ali. Construir quer dizer originalmente ${ }^{13}$ habitar. De onde a palavra construir, ainda, originariamente fala, ela diz, ao mesmo tempo, até onde a essência do habitar alcança. Construir, em suas raízes: bhu, beo corresponde ao verbo alemão "bin"14 na expressão idiomática: ich Bin, du bist, ou na forma imperativa bis, sei. O que significa então ich bin? A antiga palavra bauen, cujo "bin" pertence, responde: "ich bin", "du bist", quer dizer eu habito, tu habitas. A maneira como você é e eu sou, o modo segundo o qual nós homens somos sobre a terra, é o construir, o habitar. Ser homem quer dizer: ser mortal sobre a terra, quer dizer: habitar. A antiga palavra construir, que impõe ao homem que ele seja à medida que ele habita, significa apenas, mas ao mesmo tempo: lavrar e cultivar ${ }^{15}$, como nos exemplos: construir o campo, construir a videira. Tal construir apenas guarda o crescimento de seus frutos que amadurecem por si mesmo. No sentido de lavrar e cultivar, construir não é produzir. Por outro lado, a construção naval e a construção de um templo certamente fabricam seu próprio produto. O construir é, nesse caso, ao contrário de cultivar, um edificar. Ambos os modos de construir - construir como cultivar, colere em latim, cultura, e construir como edificar prédios, aedificare - estão retidos no construir original, o habitar. O construir como habitar, isto é, ser sobre a terra, se mantém, pois, senão para a experiência cotidiana dos homens que, de antemão, como a língua tão belamente diz: "está habituado". Por isto ele ocorre atrás dos magníficos modos pelos quais se realizam o habitar, atrás das atividades de cultivar e erigir. Essas atividades tomam para si a questão do construir a partir do resultado de suas designações e, com isto,

\footnotetext{
${ }^{13}$ O termo 'ursprünglich', segundo o dicionário DUDEN, significa: inicialmente, em primeiro lugar [disponíveis], genuínos, não adulterados, natural, terra. Neste caso pode ser traduzido por 'originalmente', uma vez que este termo no português significa 'algo próprio', 'inicial', não alterado'. Contudo, a tradução espanhola e inglesa faz uso do termo 'originariamente', no sentido de que 'oriundo de', 'nativo de', primitivo (N. do T.)

14 "O significado da raiz bhu-, bheu, bhou é provavelmente crescer (no sentido de inchar, a menos que a relação original coma raiz, a saber, b(e)u-, bh(e)u-, b(h)u-fique bem em Bausch, Beule, Busen), então 'presentar-se, ser', finalmente, viver habitalmente em algum lugar" Cf. DWDS in: http://www.dwds.de/?qu=Bauen. (N. do T.)

${ }^{15}$ Como já foi dito, originariamente, Bauen refere-se também ao exercício da agricultura (N. do. T.).
} 
tomam-na por direito. O sentido original de construir, enquanto habitar, cai no esquecimento.

Este Ereignis ${ }^{16}$ parece, em primeiro lugar, como se fosse simplesmente um caso dentro das mudanças semânticas de meras palavras. Na verdade, porém, algo decisivo se esconde lá dentro, a saber: a vivência do habitar não se dá como ser do homem; o habitar [149] nunca se dá por completo quando se pensam as características fundamentais do ser do homem.

Que a linguagem pareça aceitar de volta o significado próprio da palavra construir, a certifica, no entanto, a originariedade desse significado; então, junto às palavras essenciais da linguagem, cai facilmente no esquecimento o seu dizer próprio, em benefício do referido primeiro plano. $\mathrm{O}$ mistério desses casos, o homem ainda mal ponderou. A linguagem retira dos homens seu falar modesto e elevado. Não obstante a isto, não emudece sua exigência inicial, ela apenas silencia. O homem, sem dúvida, deixa de ater-se sobre esse silêncio.

Ouvimos, no entanto, sobre isto que a linguagem, por meio da palavra construir, diz, com efeito, ouvimos de três formas:

1. Construir é propriamente habitar.

2. Este habitar é o modo como os mortais são sobre a Terra.

3. Este construir, enquanto habitar, se desdobra em construir que cultiva, designado de desenvolvimento; e em construir que levanta construções.

Refletimos sobre essa tríplice forma, então ouvimos uma indicação e percebemos o seguinte: o que o construir edifícios for, em sua essência, nem sequer podemos questionar suficientemente ${ }^{17}$, muito menos, pois, adequadamente resolver, enquanto nós não pensarmos nisso: que cada

\footnotetext{
${ }^{16}$ O termo 'Ereignis' é um termo técnico da filosofia heideggeriana, usualmente traduzido como acontecimento apropriativo. Aqui Heidegger parece querer dar a entender que estas dissonâncias nos significados de Bauen e aclaradas pela abertura promovida pela linguagem é o próprio Ereignis, o evento apropriador que nos faz mostrar o modo de ser do homem implicado nessa fala ao significar o Bauen. Em decorrência dessa complexidade, manteremos o original em alemão (N. do T.)

${ }^{17}$ A palavra ,zureichendfragen' parece ser uma composição do adjetivo zureichend, que pode ser traduzido, segundo o Dicionário DUDEN, por aceitável, adequado, satisfatório, suficiente, etc.; e fragen, que é o verbo perguntar, interrogar, questionar. Portanto, traduzimos 'questionar suficientemente' (N. do T.)
} 
construir em si é um habitar. Nós não moramos porque construímos, antes, nós construímos e temos construído desde que moramos, isto é, desde quando somos habitantes. Contudo de onde vem a essência do habitar? Ouçamos uma vez mais a exigência da linguagem: A antiga palavra saxã "wunon", a gótica "wunian" significam igualmente, tal como a antiga palavra bauen, permanecer, deter-se. Mas a gótica "wunian" diz claramente como esse permanecer deveria ser experimentado. Wunian quer dizer: estar satisfeito, instaurar a paz em seu permanecer. A palavra paz se refere a Freie, Frye e fry que significam: proteger-se [150] do dano e da ameaça, proteger-se-de...., isto é, ter sido cuidado ${ }^{18}$. Freien significa propriamente cuidar. O cuidar se mantém independente disto: que nós nada fazemos aos que necessitam de cuidados. Propriamente, o cuidar é algo positivo e ocorre mesmo quando nós deixamos algo à frente de sua essência, mesmo quando pomos novamente a salvo expressamente algo em sua essência ${ }^{19}$, ele [o cuidar] corresponde à palavra freien: apaziguado. Habitar, feito para a paz, quer dizer: manter-se apaziguado no Frye, isto é, no Freie, cuidar de qualquer um na sua essência As características essenciais do habitar é esse cuidar. Ele perpassa o habitar em toda a sua vastidão. Esta última se mostra a nós, logo que niso pensamos, que no habitar os homens se assentam mais precisamente no sentido de permanência mortal sobre a terra.

Ora "sobre a Terra" já quer dizer "sob o céu". Ambos querem dizer "morada dos deuses" e encerram "o co-pertencer dos homens". Por meio de uma unidade original, se pertencem os quatro: a Terra, o céu, as divindades e os mortais.

A terra é o sustento servente, o fruto florescente, vastamente penduraria ${ }^{20}$ na rocha e nas águas, nascente para planta e bicharada. Dizemos

\footnotetext{
${ }^{18}$ Parece que a etimologia que Heidegger se utiliza para a palavra Frieden é do sueco: "frid" que pode ter o sentido de "estado de conservação" (Zustand der Schonung) com o sufixo "-tu"; ou "benevolência" (Woh/wollens) com a raiz "frei". Cf. Dicionário DWDS disponível in: http://www.dwds.de/?view=1\&qu=Frieden (acesso em 01/05/2016). Traduzimos o termo schonen como cuidado, mas não no mesmo sentido de Sorg, e sim no sentido de conservação, benevolência (N. do T.).

19 3a edição de 1967: Eigenes (Ereignis). (N. do A.).

${ }^{20}$ O termo "hingebreitet" não é de fácil tradução. Hinge é a forma idiomática do Konjuntiv II do verbo hängen, que significa pendurar. Breit é um adjetivo que significa amplo, vasto.
} 
terra, então, já pensamos nos outros três também, contudo não refletimos sobre a simplicidade ${ }^{21}$ dos quatro.

O céu é a incursão arqueante do sol, a forma mutante do curso lunar, o brilho vagueante dos astros, as estações do ano e suas viragens, a luz e o amanhecer do dia, a escuridão e a clareza da noite, o hospitaleiro e não hospitaleiro do tempo, a corrente de ar das nuvens e a profundidade azulante do éter. Dizemos céu, então, já pensamos nos outros três também, embora não tenhamos refletido sobre a simplicidade dos quatro.

Os deuses são os mensageiros indicantes da divindade. Por meio do agir sagrado, o Deus aparece em sua presença ou ele se retira em sua ocultação. Invocamos os deuses, então, já pensamos nos outros três também, apesar de não refletirmos sobre a simplicidade dos quatro [151].

Os mortais são os homens. Eles significam mortais porque podem morrer. Morrer significa que são capazes de morte como morte. Apenas o homem morre mais precisamente constante, enquanto ele se queda sobre a Terra, sob o céu, ante os deuses. Chamamo-nos mortais, então, pensamos já nos outros três também, embora não reflitamos na simplicidade dos quatro.

Essa sua simplicidade nomeamos Quadrângulo ${ }^{22}$. Os mortais no Quadrângulo, ao mesmo tempo, habitam. As características fundamentais do habitar é o cuidar. Os mortais habitam no modo que ele, o Quadrângulo, cuida em sua essência. Por conseguinte, o cuidar habitante é quádruplo.

Os mortais habitam na medida em que salvam a terra - tomado esse vocábulo no sentido antigo, conhecido ainda por Lessing. O salvamento arranca não apenas um perigo, salvar significa propriamente: deixar livre em sua própria essência. Salvar a terra é mais do que se aproveitar ou mesmo afanar. O Salvar a terra não a domina nem a torna um objeto, pelo qual está apenas a um passo para a exploração sem limites.

Os mortais habitam na medida em que eles acolhem o céu como céu. Eles deixam o sol e a lua seguir viagem, os astros seguir seu curso, as

A tradução portuguesa traduz por concentrar, já a inglesa por espalhar. Optamos por uma literalidade: amplamente penduraria.

${ }^{21}$ Estamos traduzindo o termo "Einfalt", seguindo um pouco as traduções que estamos tomando de base, e também pela indicação do Dicionário DUDEN. (N. do T.).

22 Encontramos para o termo "Geviert": the fourfold, a quadradatura, e cuaternidad. Traduziremos por "Quadrângulo". (N. do .T.). 
estações do ano suas bênçãos e injúrias, não tornam a noite dia e o dia uma agitada inquietação.

Os mortais habitam na medida em que eles esperam os deuses como deuses. Eles os mantêm na espera, ao encontro com o inesperado ${ }^{23}$. Eles esperam o sinal de sua chegada e não desconhecem o sinal de sua ausência. Eles não se tornam seu deus nem se dedicam a culto aos ídolos. No infortúnio, ainda esperam alcançar a salvação.

Os mortais habitam na medida em que eles, em sua própria essência, são capazes de, a saber, acompanhar no costume desta capacidade, a morte como morte, e, com isto, ter uma boa morte. Esse acompanhar os mortais [152] na essência das mortes significa de nenhum modo, estabelecer a morte no sentido de nada vazio como destino; nem quer dizer escurecer o habitar do fim.

No salvar a terra, no acolher o céu, no esperar os deuses, no acompanhar os mortais se dá o habitar como o cuidar quádruplo do Quadrângulo. Cuidar quer dizer: conservar o Quadrângulo em sua essência ${ }^{24}$. O que foi tomado sob proteção ${ }^{25}$, deveria ser posto a salvo. Ora, onde conserva o habitar, quando ele cuida da essência do Quadrângulo? Como efetivar os mortais do habitar quando estes cuidam? Os mortais reúnem a força necessária ${ }^{26}$ para que o habitar jamais seja apenas ${ }^{27}$ uma estadia sobre a terra, sob o céu, ante os deuses, com os mortais. O habitar é sempre, pelo contrário, cuidar de uma estadia junto às coisas. O habitar como cuidar conserva o Quadrângulo nele, pelo qual os mortais se detêm: nas coisas.

${ }^{23}$ O súbito outrora chegava deixando "ficar" - mas com isso (com tal deixar) ainda se achava de modo escondido (N. do A.).

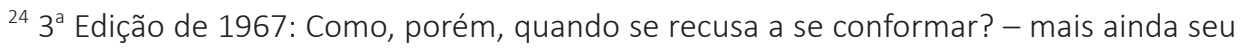
íntimo Er-eignen no dizer indica - quando então? (N. do A.)

${ }^{25}$ O vocábulo 'Hut' parece ser literalmente "chapeu” (Dicionário PONS), contudo, com base nas demais traduções, o sentido não é literal, mas figurado como o de estar debaixo de uma proteção, ser cuidado por alguma coisa. O Dicionário DUDEN apresenta o vocábulo ligado às palavras Schutz, schützende Aufsicht, Obhut, ou seja, são termos que significam proteção, supervisão e cuidado e que em sua formação incluem o vocábulo hut.

${ }^{26}$ Traduzimos, segundo o dicionário DUDEN, "vermöchten" por "reunir força necessária".

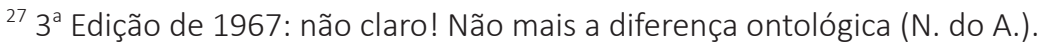


A estadia junto às coisas é, no entanto, o quádruplo indicado ${ }^{28}$ do cuidar não como algum quinto elemento apenas agregado, ao contrário: a estadia junto às coisas é o modo único, como se a estadia quádrupla no Quadrângulo, uma de cada vez, se efetuasse uniformemente. O habitar cuida do Quadrângulo quando ele leva as coisas para a essência ${ }^{29}$. Só as coisas mesmas põem a salvo o Quadrângulo, unicamente quando se deixar serem elas mesmas como coisas em sua essência ${ }^{30}$. Como se daria isto? Desse modo, que os mortais lavrem e cultivem o crescimento ${ }^{31}$ não o crescer, especialmente como edificar. O cultivar e o edificar são o construir em sentido próprio. O habitar é na medida em que ele conserva o Quadrângulo nas coisas, quando esse conservar é um construir. Com isto nós estamos a caminho da segunda parte da pergunta [153]:

\section{II}

Até que ponto o construir pertence ao habitar?

A resposta a esta pergunta nos esclarece o que o construir, recordado pela essência do habitar, propriamente é. Nós nos limitamos ao construir no sentido de edificar das coisas e perguntamos: o que é uma coisa construída? Como exemplo, serve para nós a reflexão sobre uma ponte.

A ponte balança "suave e forte" sobre a torrente. Ela não une apenas só a margem existente. Na travessia, a ponte toca a margem primeiramente como margem à frente. A ponte a deixa expressamente uma contra a outra se encontrar. O outro lado é posto em direção ao primeiro por meio da ponte. A margem tampouco se estende como algo que levemente toca a fronteira e de modo indiferente ${ }^{32}$ à terra firme ao longo da torrente. A

\footnotetext{
28 Traduzimos "Vierfalt" tal como "vierfältige".

${ }^{29}$ 3a Edição de 1967: característico- .

30 3a Edição de 1967: próprio.

${ }^{31}$ Seguindo a referência da tradução portuguesa, traduziu-se wachstümlichen como wachstum.

${ }^{32}$ A expressão "gleichgültige Grenzstreifen" foi traduzida literalmente e de modo descritivo, pois "gleichgültig" significa indiferente, "Grenze" quer dizer fronteira, e "streifen" é um verbo que pode ser traduzido como tocar (mas de leve), segundo o Dicionário PONS. Daí, retiramos nossa tradução (N. do T.).
} 
ponte leva com margem, a cada vez, uma e outra, a vastidão da parte de trás da paisagem da margem junto à torrente. Ela leva a torrente, a margem e a terra para uma proximidade recíproca. A ponte reúne a terra como paisagem ao redor da torrente. Assim ela a acompanha pelas planícies ${ }^{33}$. A sustentação da ponte suporta, o agitante leito da torrente, o vigor do arco que deixa as águas das torrentes em seu curso. A água deseja caminhar quieta e animada, as águas do céu junto às trovoadas ou o degelo na onda torrencial desejam se lançar ao redor do arco de sustentação, a ponte está preparada para o clima do céu e sua essência. Além disso, lá onde a ponte encobre a torrente, ela mantém fechado suas correntezas desse modo do céu, que ela acolhe e daí de novo libertar para o momento no arco.

A ponte deixa a torrente em seu curso e abriga, ao mesmo tempo, os mortais em seu caminho, que de terra em terra vêm e vão. Pontes acompanham sobre magníficos modos. Pontes urbanas conduzem da área do castelo para a praça da catedral, pontes sobre rios, junto aos vilarejos, levam carroças e comboios para as aldeias vizinhas [154]. A imperceptível passagem sobre córrego da antiga ponte de pedra dá ao veículo da colheita seu caminho desde a campina nas aldeias, carrega a carga de madeira da estrada de chão para estrada principal. A ponte rodoviária é calculadamente colocada na linha do metrô e possibilita um trânsito rápido. Sempre, e nunca de outro modo, a ponte acompanha aqui e ali o hesitante e precipitado caminho dos homens, que para a outra margem e por fim, no caso dos mortais, chegam ao outro lado. A ponte oscila para cima, oscila na superfície das curvas do rio e do barranco; se os mortais guardam ou se esquecem do oscilante caminho da ponte no cuidado, então eles, sempre no caminho para última ponte, se esforçam em razão disso, para superar seu habitual e infortúnio ao redor de si para trazer a salvação dos deuses. A ponte reúne, tal como a oscilante passagem, para os deuses. Devo agradecer a propriedade expressamente ponderada e com certeza ser como na figura da ponte sagrada, devo mudar em absoluto, ou permanecer empurrando o caminho.

A ponte reúne, a seu modo, terra e céu, os deuses e os mortais junto de si.

${ }^{33}$ Segundo o dicionário DUDEN, "Auen" está ligado à planície (N. do T.). 
Reunião quer dizer, conforme uma antiga palavra de nossa língua, 'thing'. A ponte é - e, na verdade, tal como assinalada Reunião dos Quadrângulos - uma coisa. Cremos, no entanto, que pontes fossem primeiramente e propriamente nada mais que uma ponte. Adicionalmente e Ocasionalmente ela pode expressar, ainda de vários modos, mais do que isso. Em uma palavra, ela deveria ser, então, símbolo, por exemplo, para tudo isto que há pouco foi nomeado. Nunca a ponte é somente, onde ela é uma autêntica ponte, em primeiro lugar, nada mais que ponte e depois um símbolo. A ponte é igualmente e, de antemão, apenas um símbolo, no sentido que ela expressa algo, quando ela não é rigorosamente tomada para seu pertencer. Quando tomamos a ponte rigorosamente, nunca a indicamos mesmo como expressão. A ponte é uma coisa e apenas isto. Apenas? Com essa coisa ela reúne o Quadrângulo.

Nosso pensar está acostumado, no entanto, desde o imemorial, moldar ${ }^{34}$ precariamente a essência das coisas. Isto tem por resultado, no curso do pensamento ocidental, que agente apresenta as coisas como um [155] estranho $\mathrm{X}$, isto está perceptivelmente marcado com propriedade. Visto daí, nos parece, no entanto, que essas coisas já pertencem às essências reunidas, todas, como um ingrediente suplementar interpretadamente acrescido. Contudo jamais seria a ponte somente uma ponte, ela não seria uma coisa.

A ponte é, no entanto, uma coisa de modo próprio; pois ela reúne o Quadrângulo neste modo, que ela o oportuniza ${ }^{35}$. Mas apenas tal status ${ }^{36}$, que é mesmo um lugar, pode arranjar um Status. O lugar não existe antes da ponte. Na verdade, antes da ponte, está dado, ao longo da torrente, muitos lugares, que podem ser ocupados por alguma coisa. Um entre eles se mostra como um lugare, na verdade, se mostra por meio da ponte. Assim, pois, a ponte não chega ficar aí primeiramente em um lugar, mas antes

\footnotetext{
${ }^{34}$ O verbo 'anzusetzen' não é de fácil tradução. No dicionário DUDEN, o utilizam como 'moldagem' (Schimmel anzusetzen). Há o verbo ansetzen que significa por, unir, ligar, ganhar, fixar e começar. Utilizando como base a tradução portuguesa, traduzimos como moldar.

${ }^{35}$ Não conseguimos tradução específica para 'verstattet', nem um acordo entre as traduções que tomamos por base. Portanto traduzimos pelo contexto do texto e optamos por oportunizar, no sentido de criar um espaço importante para se dar.

36 "Stätte", segundo o Dicionário DUDEN significa um espaço que possui uma finalidade específica. Assim, traduzimos por status. (N. do A.).
} 
mesmo da ponte, surge aí primeiramente um lugar. Ela é uma coisa, reúne o Quadrângulo, reúne cada um no modo que ela oportuniza o Quadrângulo em um status. Sobre esse status se determinam os lugares e os caminhos pelos quais foi arranjado um espaço ${ }^{37}$.

Coisas, que são em tal modo lugar, oportunizam, primeiro e a cada vez, áreas físicas. O que esta palavra "Raum" (espaço) designa, diz seu velho significado. Raum, Rum quer dizer lugar geográfico libertado para urbanização e armazenagem. Um espaço é algo arranjado ${ }^{38}$, liberado, a

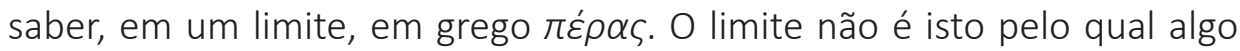
termina, antes, como os gregos reconheceram, o limite, isto desde onde

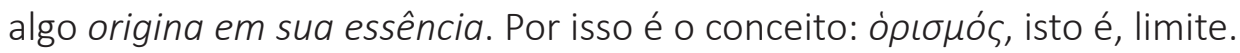
Espaço é a apreensão essencial do arranjado, deixado em seu limite. Esse arranjado deveria cada vez permitir e, assim estruturar, isto é, reunir por meio de um lugar, ou ainda, por meio de uma coisa, a partir do modo da ponte. Logo as áreas físicas acolheram as essências delas da essência dos lugares e não "da" do espaço.

Coisas, que oportunizam um status como lugares, nós tomamos agora antecipadamente como construir. Elas querem dizer assim, porque elas, por meio do construir edificante, são produção. Contudo algum modo desse produzir [156], a saber, desse construir, deve ser experimentado por nós, somente quando, antes, tivermos ponderado a essência dessas coisas, isto exige a partir de si que exista, para sua produção, o construir como produzir. Essas coisas são lugares, que oportunizam no Quadrângulo um status, arranjam a cada vez um espaço. Na essência destas coisas, como lugares, situa a referência ao lugar e ao espaço, mas também situa a relação entre o lugar e os homens, que se detém nele. Por isto experimentamos agora a essência dessas coisas, que tomamos por construir, para esclarecer, desse modo, que nós brevemente seguimos em nosso pensar.

\footnotetext{
${ }^{37}$ De acordo com o dicionário DUDEN, o vocábulo "Raum" tem a haver com espaço construído, residencial, lugar fechado, espaço matemático, espaço geográfico, área medida em largura, comprimento.

38 Para a tradução do vocábulo "Eingeräumtes", recorremos ao verbo einräumen, que significa arrumar, no sentido de deixar alguma coisa organizada. Optamos por traduzir Eingeräumtes como arranjado, no sentido de arranjo, como nos exemplos: arranjo de flores, reforçando o sentido de algo produzido e organizado pelo homem.
} 
Afinal: em que relação está lugar e espaço? Por outro lado: qual é a relação entre homens e espaço?

A ponte é um lugar. A coisa enquanto tal a oportuniza em um espaço, permite estar na terra e céu, nos deuses e mortais. O espaço oportunizado a partir da ponte contém vários lugares em diferentes proximidades e distâncias da ponte. Esses lugares se deixam, agora, pôr, mas puramente como lugar, entre eles existe uma distância mensurável; uma distância, em grego

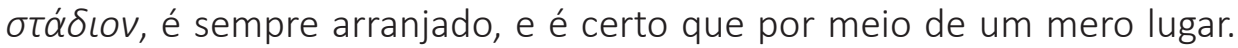
Isto assim, a partir do lugar arranjado, é um modo próprio do espaço. Ele é como a distância, como estádio, que, como nos diz a mesma palavra estádio latinizada, um "spatium", um intervalo. Desse modo, poderia a proximidade e a distância entre homens e coisas ser um mero afastamento, distâncias de intervalos. Em um espaço, que é simplesmente apresentado como spatium, a ponte aparece agora como um mero algo em um lugar, cujo lugar poderia ser substituído a qualquer hora por qualquer outra coisa ocupada ou por meio de uma mera marcação. Não o suficiente se deixa destacar ${ }^{39}$, pelo espaço como intervalo, a mera extensão ${ }^{40}$ conforme a altura, largura e profundidade. Isto, desse modo desnudado, latiniza abstractum. Pomos como pura variedade as três dimensões. O que, contudo, arranja essa variedade, não deveria também determinar mais do que distâncias, não é nada mais que spatium, mas apenas ainda extensio - extensão. O espaço como extensio se deixa deduzir, mas outra vez [157], a saber, sobre uma relação analítico-algébrica. O que esse arranjo é, é a possibilidade de uma construção puramente matemática de variedades com muitas dimensões quaisquer. Pode-se tomar esse arranjo matemático como "o" espaço. Mas "o" espaço, nesse sentido, não contém áreas físicas e lugares. Nós nunca encontramos nele lugares, por exemplo, coisas a maneira de ponte. Bem ao encontro disto está o inverso, nas áreas físicas que são arranjadas por meio dos lugares a qualquer momento o espaço como intervalo e nestas reassume o espaço como uma pura extensão. Spatium e extensio sempre dão a possibilidade

\footnotetext{
${ }^{39}$ O vocábulo "herausheben" foi traduzido como "destacar" por sugestão do dicionário DUDEN.

${ }^{40}$ O vocábulo "Ausspannungen" foi traduzido como "extensão", pela indicação que o verbo ausspannen tem: estender.
} 
das coisas e isso, o que elas arranjam, conforme as distâncias, a extensão ${ }^{41}$, a direção para mensurar e a medida para calcular. Contudo, em nenhum caso, são as medidas numéricas e suas dimensões apenas para isso, pois elas são aplicáveis a todos os extensos em geral, ademais o fundamento para a essência das áreas físicas e lugares são mensuráveis com a ajuda da matemática. Em certa medida, também a física moderna, por meio da coisa em si mesmo, foi obrigada a apresentar o Médium espacial do espaço cósmico como uma unidade de campo, por meio do corpo como foi determinado o centro dinâmico, que aqui não há condições de ser discutido.

As áreas físicas, que nós cotidianamente atravessamos, são arranjadas pelos lugares; se fundamentam, desde a essência, nas coisas pelo modo das construções. Nós cuidamos destas relações entre lugar e áreas físicas, entre áreas físicas e espaço, então nós chegamos a refletir sobre uma explicação ${ }^{42}$, a redor dessa relação de homens e espaço.

É o discurso do homem e do espaço, pois, que se ouve ao redor, enquanto o homem estaria de um lado e o espaço estaria de outro. Contudo o espaço não é um vis-à-vis para o homem. Nem é um objeto exterior a ele nem uma vivência interior. Não há homens separados do espaço; pois digo "um homem" e penso em ambos com essa palavra, este é modo humano que quer dizer vivente, já que designo com o nome [158] "um homem" a permanência no Quadrângulo junto às coisas. Mesmo quando nos comportamos junto às coisas que não estão acessivelmente próximas, nós nos demoramos com as coisas. Colocamos as coisas distantes não somente - como agente ensina - [como algo] para interior, de tal modo que, como substituição para coisas distantes de nosso interior e de nossa cabeça, decorre apenas de sua representação. Quando nós agora - todos nós - pensamos aqui de fora ao pé da antiga ponte em Heidelberg, então este pensar ${ }^{43}$ aquele lugar não é agora somente uma vivência de alguém presente, ao contrário pertence à essência de nosso pensar junto à indicada ponte que esse pensar em si resiste à distância para esse lugar. Nós estamos daqui de fora junto à ponte

\footnotetext{
41 Traduzimos "Strekken" com o mesmo sentido de "Strecke".

42 Por sugestão do Dicionário DUDEN, traduzimos Anhalt por "explicação".

43 "Hindenken" é usado em perguntas com indignação como: "wo denken Sie hin?". Traduzimos por "pensar"
} 
e não, por exemplo, junto a um conteúdo de representação em nossa consciência. Nós podemos até, a partir daqui e por meio dessa ponte, e disto que ela arranja, estar mais próximos do que alguém que cotidianamente a utiliza como travessia sobre rio. Áreas físicas e com elas "o" espaço já são arranjados continuamente nesta permanência dos mortais. Áreas físicas se abrem por aí, pois elas são admitidas no habitar dos homens. Os mortais são, isto diz: habitantes resistem às áreas físicas em razão de sua permanência junto às coisas e lugares. E apenas porque os mortais resistem a essência delas, conforme áreas físicas, eles podem aceitá-las. Pois com o partir não perdemos o ficar. Pelo contrário, nós partimos sempre assim por meio das áreas físicas, que nisso já suportamos, posto que nós nos mantenhamos continuamente próximos e distantes junto aos lugares e às coisas. Quando eu vou para a fim dos salões, já estou lá e nunca posso passar, quando eu não estiver assim, então eu estou aí. Eu nunca estou apenas aqui como corpo este fechado, ao contrário eu estou aqui, por exemplo, este espaço já resiste e apenas assim eu posso aceitá-lo.

Mesmo então, quando os mortais "si vão", eles não deixam a pertença ao Quadrângulo. Quando nós - como agente diz - refletimos sobre nós mesmos, nos erguemos aqui da diminuição frente às coisas, sem nunca deixar esta permanência junto às coisas. Até a perda de referência para as coisas, que aparece [159] em uma situação depressiva, seria impossível, tampouco quando esse estado de permanência, que ele como um humano é, a saber, uma permanência junto às coisas. Apenas quando esse permanecer dos humanos já determinado chegamo-nos às coisas, somos junto delas, tampouco nos dirigimos, tampouco lidamos mais.

Quando refletimos sobre o experimentado modo de relação entre lugar e espaço, mas também a relação entre homem e espaço, recai uma luz sobre a essência das coisas, somos lugares e designamos construções.

A ponte é uma coisa de tal modo. O lugar admite a simplicidade da terra e do céu, dos deuses e dos mortais no status, enquanto ela edifica o status nas áreas físicas. O lugar arranja o Quadrângulo em um duplo sentido. O lugar consente o Quadrângulo e o lugar edifica o Quadrângulo. Ambos, a saber, arranjar como permissão e arranjar como edificar, co-pertencem. Com esse duplo arranjo é o lugar uma proteção do Quadrângulo ou como a 
mesma palavra diz: um Huis, uma Haus. Coisas, deste tal modo de lugares, são capazes de abrigar a permanência dos homens. Coisas desse modo são habitações, mas não necessariamente habitações em sentido próprio.

A produção de tal coisa é o construir. Sua essência se baseia nisso, que ela satisfaz o modo das coisas. Elas são lugares, oportunizar as áreas físicas. Por isso é o construir, pois edifica os lugares, um instituir e um conformar de áreas físicas. Porque o construir produz lugares, chega com a conformação de suas áreas físicas necessárias também ao espaço como spatium e como extensio na reificada estrutura das construções. Sozinho o construir nunca coloca "o" espaço. Nem imediato nem mediato [160]. Todavia é o construir, pois ele produz coisas como lugares, da essência das áreas físicas e da origem essencial "dos" espaços mais próximos como geométrico e matemático. 0 construir edifica os lugares, que arranja no Quadrângulo um status. Sobre a simplicidade, na terra e no céu, nos deuses e nos mortos pertence um ao outro, recebe o construir a instrução para seu construir desde os lugares. Em função do Quadrângulo se empreende o construir da medida para todos os diâmetros e cada metro das áreas físicas, são arranjados a cada vez e por meio dos lugares fundados. As construções conservam o Quadrângulo. Elas são coisas, que cuidam sobre as essências delas o Quadrângulo. Cuidar do Quadrângulo, salvar a terra, receber o céu, esperar os deuses, acompanhar os mortais estes quatro cuidados é a simplicidade essencial do habitar. Assim marcar, pois, o autêntico construir do habitar na sua essência é capaz de abrigar essa essência.

Esse construir distinguido é um excelente deixar-habitar. Ele é isto no ato, pois satisfez o construir já na exigência do Quadrângulo. Em função desse satisfazer permanecem fundados todos planos, isto por seu lado abre o projeto para a ruptura da área medida.

Mal tentamos, pensar a essência das edificações pelo deixar-habitar, e logo experimentamos germanicamente onde essa produção se baseia, como algo que se efetiva no construir. Habitualmente tomamos a produção como uma atividade, um resultado do trabalho, construção de edifício, ter um resultado. Pode-se apresentar a produção assim: conceber algo certo e, contudo, nunca encontrar sua essência, isto é um chegar, que apresenta. O construir traz, a saber, o Quadrângulo aqui em uma coisa, a ponte, e 
traz a coisa como um lugar por meio do já presente, que é arranjado agora primeiramente por meio deste lugar.

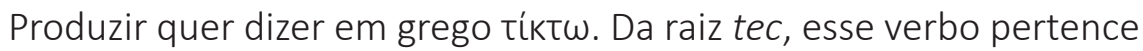
à palavra $\tau \varepsilon \chi \chi v \eta$, técnica. Isto significa para os gregos nem arte nem ofício, apenas: deixar aparecer algo como isto ou aquilo de tal modo ou de outra maneira no presente [161]. Os gregos pensavam que $\tau \varepsilon ́ \chi \vee \eta$, esse produzir, a partir do deixar-aparecer aqui. Isto assim para pensante $\tau \dot{\chi} \chi v \eta$ se oculta desde a imemorial arquitetônica. Ela se esconde ultimamente ainda e determinantemente na tecnologia dos motores. Mas a essência dos produtos construídos nem se deixa adequadamente pensar em arte de construir nem engenharia civil, nem numa mera vinculação. Esse produto construído seria tampouco, pois, adequadamente determinado, queremos pensá-lo no

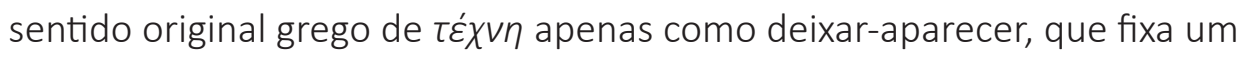
resultado como presentes já no presente.

A essência das construções é o deixar-habitar. A efetivação essencial das construções é o edificar dos lugares por meio da submissão de suas árvores. Apenas quando somos capazes de habitar, poderemos construir. Pensemos por um tempo junto a uma Floresta Negra, que, por dois séculos, ainda abrigou habitações rústicas. Lá a insistência da capacidade de deixar entrar terra e céu, deuses e os simples mortais nas coisas pode ser visualizada a partir de uma casa. Esta tem abrigado o pátio colocado ao pé da encosta da montanha ao meio-dia entre a estepe na proximidade da fonte. Há nela um longo telhado, que na inclinação apropriada suporta cargas de neve e suficientemente para proteger os moradores contra as tempestades das longas noites de inverno. Ela não se esqueceu do canto dos deuses atrás da mesa comum, ela tem os lugares sagrados para a cama da criança e para o Totenbaum, de tal modo que ali quer dizer o caixão, arranjado no quarto, e assim as diferentes experiências vividas sob um telhado caracterizam o retorno delas por meio do tempo prefigurado. Um trabalho manual, de onde provém o habitar, precisa de seus instrumentos e suas estruturas mais do que coisas construídas no pátio.

Apenas quando nós somos capazes de habitar é que podemos construir. A referência à Floresta Negra de modo nenhum quer dizer que nós havíamos e devíamos voltar a construir esses pátios, pelo contrário, ela ilustra uma habitação essencial, como deveria ser uma construção [162]. 
O habitar, pois, é a característica fundamental dos entes, em acordo com aquilo que os mortais são. Em função dessa tentativa, talvez, conseguimos refletir sobre o habitar e o construir, em torno de uma mais clara luz, que o construir pertence ao habitar e como dele acolhe sua essência. Estaria suficientemente alcançado quando habitar e construir chegasse ao digno de ser questionado e assim tornasse digno de ser pensado.

Então, todavia, até o pensar, no mesmo sentido do construir, apenas em outro modo, pertence ao habitar, quer-se, agora, tentar atestar o caminho do pensar.

Construir e pensar são, a cada vez, conforme seus modos, indispensáveis para o habitar. Ambos são, porém, também, insuficientes para o habitar, enquanto eles se movem separados, em vez de ouvir um ao outro. Eles serão capazes disto quando ambos, construir e pensar, pertencerem ao habitar, saberem e permanecerem em seus limites, que chegam um como o outro pelo ofício de uma longa experiência e um contínuo exercício.

Tentamos refletir sobre a essência das habitações. O próximo passo nesse caminho seria a pergunta: como ele fica com o habitar em tempos críticos como os nossos? Fala-se em toda a parte e com razão da crise habitacional. Não se diz apenas, mete a mão. Tenta-se remediar a ausência por meio da aquisição de habitações, por meio de subsídio de construções habitacionais, por meio do planejamento de construções de toda natureza. Tão dura e intensa quanto detida e ameaçadora permanece a carência de habitações, propriamente, a ausência de habitações não se encontra primeiro na falta de habitações. A crise habitacional propriamente é ademais antiga como a guerra mundial e a destruição, antiga, além disso, por causa do aumento da população sobre a terra e a situação dos trabalhadores industriais. A ausência das habitações propriamente se baseia nisto que os mortais sempre e primeiro tornam a buscar a essência das habitações, que eles devem primeiro aprender a habitar. Enquanto a apatricidade dos homens se mantiver nisso, como que o homem que afinal reflete sobre a crise habitacional ainda não a refletiu como ausência? Logo que o homem, todavia, reflete a apatricidade não é ela já [163] mera miséria. Ela está bem pensada e bem guardada, a única exigência, evoca os mortais ao habitar. 
Em outras palavras, podem os mortais corresponder como caracterizado a esta exigência que tenta, junto a sua parte, por si só, trazer aqui o habitar na completude de sua essência? Ele realiza isso quando constrói sobre o habitar e pensa em direção ao habitar. 